\title{
ESTIMASI TUJUAN PENUMPANG MENGGUNAKAN PREDICTIVE MODEL DENGAN DATA SMART CARD
}

\author{
Inkreswari Retno Hardini ${ }^{1}$, Goklas Henry Agus Panjaitan ${ }^{2}$, Ekky Novriza Alam ${ }^{3}$, Sita Rosida ${ }^{4}$ \\ Sekolah Teknik Elektro dan Informatika \\ Institut Teknologi Bandung Bandung, \\ Indonesia \\ inkreswari@gmail.com ${ }^{1}$, goklasif10029@gmail.com²,23517006@std.stei.itb.ac.id ${ }^{3}$, \\ 23517025@std.stei.itb.ac.id ${ }^{4}$
}

\begin{abstract}
Bus Rapid Transit (BRT) is one of the main choices of public transportation that supports mobility of Jakarta community. As one of the main choices of public transportation, BRT should provide good service and always improve its performance. Needs for moving or mobility will cause a problem if the moving itself is heading at the same area and at the same time. That will cause some problems which are often faced in urban areas such as traffic and delay. To overcome those problems there needs to be a strategy to build good public transportation planning, besides need to know individual travel patterns to overcome problems and improve BRT service. In case to realize those plans needs to be built origin-destination $(O-D)$ matrix. $O-D$ matrix is a matrix that each cell is an amount of trip from the source(row) to the destination (column). $O-D$ matrix is beneficial for analysis, design and public transportation management. O-D matrix also provides useful information like amount of trip between 2 different locations, that can be utilized as fundamental information for decision making for three levels of strategic management (long term planning), tactic (service adjustment and network development), and operational (scheduling, passenger statistic, and performance indicator). To build $O-D$ matrix is required a predictive model that can be measured to predict passenger destination. The predictive model will be build using classification algorithms such as Decision Tree and K-Nearest Neighbor $(K N N)$
\end{abstract}

Keywords—predictive model, classification, decision tree, $k$-nearest neighbor, bus rapid transit.

\section{Pendahuluan}

Kebutuhan akan pergerakan akan mengakibatkan permasalahan, apabila terjadi pergerakan untuk tujuan yang sama disuatu daerah dan dalam waktu yang bersamaan, tentunya akan menyebabkan permasalahan yaitu kemacetan dan keterlambatan. Bus rapid transit merupakan salah satu transportasi umum yang menunjang aktivitas pergerakan masyarakat Jakarta. Oleh karenanya bus rapid transit (BRT) harus dapat memberikan layanan yang baik dan senantiasa memperbaiki kinerja. Layanan yang baik dapat diukur dari berbagai macam indikator, beberapa diantaranya adalah waktu tunggu penumpang di halte, tingkat kepadatan penumpang didalam sebuah bus yang harus sesuai dengan kapasitas, dan kemudahan pengumpulan tarif perjalanan.

Untuk meningkatkan layanan BRT serta untuk mengatasi permasalahan yang terjadi seperti kemacetan dan keterlambatan, maka harus diketahui pola jumlah kebutuhan transportasi dan pola individu penumpang. Informasi mengenai kedua hal tersebut dapat diperoleh melalui matriks origin-destination. Matriks origin-destination adalah matriks yang setiap selnya merupakan jumlah perjalanan dari titik asal (baris) ke tujuan (kolom) [1][2].

Untuk meningkatkan kualitas dan keefektifan transportasi umum, diterapkanlah automated fare collection (AFC), atau dikenal sebagai transit smart card (SC). Data transaksi yang terekam melalui AFC memungkinkan untuk memberikan pengetahuan atau insight baru yang bermanfaat bagi ilmu pengetahuan, tetapi diperlukan metodologi untuk mengekstrak pengetahuan tersebut karena kebanyakan sistem AFC awalnya tidak dirancang untuk pengumpulan data [3].

Data transaksi smart card melalui Automated fare collection (AFC) sistem menjadi sumber informasi utama untuk membuat matriks origin-destination (O-D) transportasi 
umum. Dengan adanya sumber informasi tersebut, memungkinkan pemahaman yang lebih baik tentang pola perjalanan individu dan perencanaan strategis terkait transportasi umum kualitasnya semakin meningkat karena ditunjang data yang real. Matriks O-D penting untuk analisis, desain, dan manajemen transportasi umum. Selain itu informasi yang terkandung adalah mengenai jumlah perjalanan antara dua lokasi yang berbeda, yang dapat dimanfaatkan sebagai informasi dasar pengambil keputusan untuk tiga tingkatan manajemen strategis, taktis, dan operasional [3][4][5][6][7].

Pada masa awal beroperasi, BRT Transjakarta menggunakan sistem entry-only. Lalu bertambahnya waktu, bus rapid transit Transjakarta mulai menggunakan sistem yang merekam transaksi asal dan tujuan penumpang setiap harinya, yang bernama AFC entryexit. Namun, data transaksi yang terekam oleh system AFC tidak dapat merepresentasikan keseluruhan data penumpang asal dan tujuan karena kendala infrastruktur yang masih belum sepenuhnya berfungsi dan perilaku penumpang yang tidak taat [8].

Mengingat system AFC yang digunakan serta sumber data yang dimiliki keduanya berbeda, maka diperlukanlah proses pengolahan data yang berbeda pula untuk membentuk matriks O-D. Terdapat penelitian yang menggunakan model Trip-chaining yang merupakan metode yang paling banyak digunakan untuk melakukan estimasi tujuan penumpang pada system entry-only untuk membuat matriks O-D [6]. Trip-chaining model pertama kali diterapkan di New York untuk keperluan menyimpulkan tujuan penumpang. Hal tersebut dilakukan dengan menggunakan dua asumsi utama yaitu stasiun tujuan dari perjalanan saat ini merupakan stasiun asal dari perjalanan berikutnya dan sebagian besar pengguna transportasi umum mengakhiri perjalanannya pada stasiun mereka memulai perjalanan pada hari tersebut [9]. Kemudian dalam penelitian yang dilakukan oleh Zhao terdapat asumsi tambahan bahwa penumpang menggunakan jenis transportasi yang sama diantara dua perjalanan tersebut [10].

Terdapat penelitian yang menggunakan analisis big data untuk mengestimasi matriks O-D BRT Transjakarta dengan menggunakan data entry-only dan model trip-chaining. Penelitian tersebut berhasil membangun matriks O-D tetapi 36,5\% transaksi penumpang tidak dapat diprediksi [8]. Oleh karena itu diperlukan predictive model yang dapat diukur untuk melakukan prediksi tujuan penumpang yang dapat diukur untuk melakukan prediksi tujuan penumpang yang dapat dimanfaatkan untuk membangun matriks $\mathrm{O}-\mathrm{D}$.

Predictive model dapat dilakukan dengan menggunakan algoritma klasifikasi seperti decision tree yang telah dilakukan dalam penelitian [11] untuk prediksi tujuan pengemudi dan pernah digunakan juga untuk prediksi yang menggunakan mobile data [12]. Algoritma klasifikasi lainnya yang dapat digunakan yaitu K-Nearests Neighbor yang pernah digunakan dalam penelitian [13][14] untuk melakukan prediksi tujuan dan rute kapal dengan menggunakan data Automatic Identification System (AIS). Algoritma klasifikasi ini dapat menjadi alternative untuk membangun predictive model dengan data transaksi smart card BRT.

Melalui prediksi estimasi tujuan penumpang yang akurat, diharapkan dapat membantu dalam pembentukan perencanaan strategis sehingga dapat mengurangi keterlambatan operasional BRT, kepadatan penumpang dan kemudahan pengumpulan tarif penumpang. Konsep ini peningkatan layanan menjadi lebih efektif dan efisien ini tentunya sejalan dengan konsep future service di dunia industri [15].

\section{Metode}

\section{A. Rancangan Solusi}

Untuk membentuk matriks origin-destination menggunakan data transaksi smart card penumpang transportasi umum diperlukan informasi asal dan tujuan penumpang. Sebagian besar sistem AFC merekam informasi asal perjalanan tetapi tidak merekam informasi tujuan perjalanan penumpang. Dari batasan yang diberikan oleh penerapan sistem AFC, model trip-chaining merupakan metode yang paling sering digunakan untuk melakukan 
prediksi tujuan perjalanan penumpang. Namun hasil prediksi tujuan penumpang yang dihasilkan oleh model trip-chaining akan sulit untuk melakukan pengujian tanpa data yang cukup dan memadai.

Dengan menggunakan data dari sistem AFC entry-exit dari sumber data, data asal dan tujuan perjalanan penumpang dijadikan sebagai data yang sudah berlabel untuk membangun model predisksi terhadap tujuan penumpang dengan menggunakan algoritma decision tree dan KNN. Dua algoritma ini digunakan karena berhasil digunakan oleh penelitian terdahulu untuk memprediksi tujuan pada domain yang berbeda [13][12][14].

Berdasarkan data yang dimiliki dan pengaturan rute transportasi umum, prediksi terhadap tujuan dapat dikelompokkan menjadi tiga, yaitu halte tujuan, sub-koridor tujuan, dan koridor tujuan. Halte tujuan penumpang diprediksi untuk mengetahui secara detail OD dari suatu halte ke halte lain. Sub-koridor tujuan penumpang diprediksi untuk mengetahui O-D dari bagian koridor. Sedangkan koridor tujuan diketahui untuk mengetahui jumlah transit antar koridor.

Untuk membangun predictive model maka data asal dan tujuan penumpang akan dibagi menjadi training set dan testing set. Kedua model ini akan digunakan untuk kemungkinan solusi dalam membentuk matriks origin-destination yang dapar diuji. Hasil algoritma ini dibandingkan untuk membentuk matriks origin-destination.

\section{1) Tahapan Solusi}

Untuk melakukan prediksi tujuan perjalanan penumpang dengan menggunakan data transaksi smart card, maka dilakukan 4 tahapan utama yaitu praproses, training model, evaluasi model dan analisis model prediksi yang ditunjukkan pada Gambar 1 .

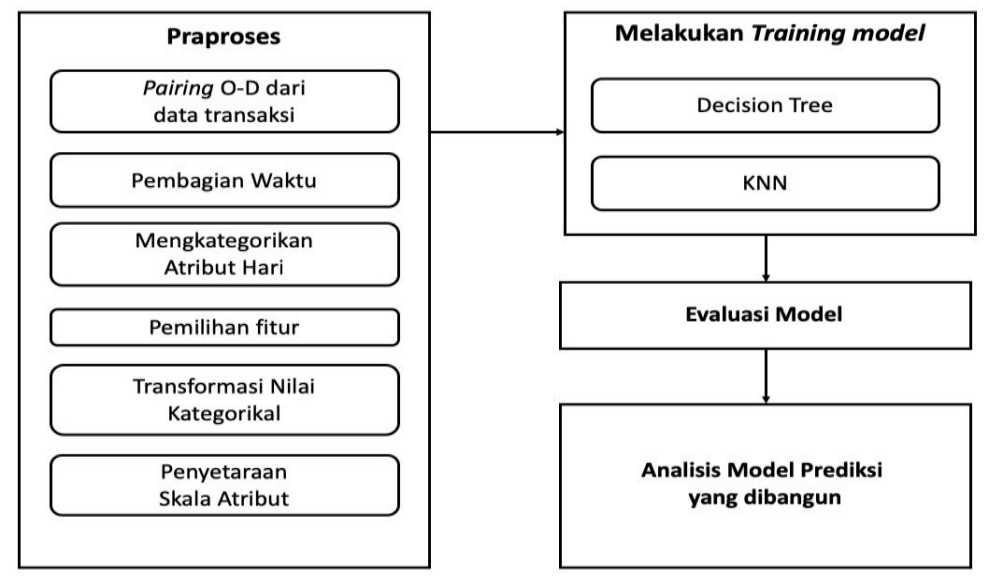

Gambar 1. Tahapan Solusi

\section{2) Evaluasi Rancangan Solusi}

Evaluasi model yang dibangun untuk memprediksi tujuan penumpang, dilakukan dengan pengujian sisi akurasi terhadap data uji. Pengukuran akurasi menggunakan matriks akurasi. Model pengukuran menggunakan matriks akurasi dipilih karena hasil prediksi berupa klasifikasi atau prediksi benar atau salah. Untuk dapat membangun matriks akurasi, maka perlu dihitung jumlah tujuan penumpang yang benar terhadap data uji. Hasil prediksi benar (true positive), jumlah transaksi yang salah diprediksi (false positive), jumlah transaksi yang gagal (false negative).

Setelah nilai matriks akurasi didapatkan maka dapat dihitung precision dan recall. Kedua pengukuran ini cukup baik memberikan hasil terhadap model prediksi. Precision merepresentasikan tingkat ketepatan model untuk memprediksi tujuan perjalanan penumpang. Sedangkan recall merepresentasikan kemampuan model untuk memprediksi seluruh tujuan perjalanan penumpang. 
Untuk menentukan akurasi dari prediksi berdasarkan kedua nilai (precision dan recall) yang merepresentasikan makna yang berbeda, maka dilakukan perhitungan $f$-measure untuk menggabungkan kedua nilai tersebut (precision dan recall) dan didefinisikan sebagai pengukuran tunggal

\section{B. Pengumpulan Data}

\section{1) Sumber Data}

Sumber data yang digunakan berasal dari data transaksi smart card yang didapatkan dari Badan Usaha Bus Rapid Transit Jakarta.

\section{2) Deskripsi Data}

Data yang digunakan merupakan data transaksi smart card penumpang BRT Transjakarta yang direkam melalui sistem AFC. Sistem AFC yang diterapkan oleh BRT Transjakarta menggunakan sistem AFC entry-exit yang merekam informasi asal dan tujuan penumpang. Setiap kali penumpang keluar masuk halte akan direkam sebagai satu transaksi. Informasi yang disimpan setiap kali transaksi yaitu timestamp, id kartu, bank penerbit kartu, koridor, subkoridor, halte, dan jenis transaksi keluar atau masuk halte. Dari data diketahui terdapat 13 koridor yang terbagi menjadi 43 sub-koridor. Dalam 43 sub-koridor terdapat total 233 halte. Data transaksi smart card mencakup atribut-atribut yang tertera pada Tabel 1 .

Tabel 1. Deskripsi Data

\begin{tabular}{ll}
\hline Atribut & Deskripsi \\
\hline tanggal jam & Tanggal dan jam penumpang melakukan transaksi \\
\hline id kartu & Nomor kartu \\
\hline kartu & Jenis kartu yang digunakan \\
\hline koridor & Jalur/koridor BRT asal perjalanan penumpang \\
\hline subkoridor & pembagian zona koridor asal perjalanan penumpang \\
\hline halte & Halte asal penumpang \\
\hline flag & In/out \\
\hline
\end{tabular}

Jumlah data yang didapatkan sebanyak 16.099.914 data dan setelah melakukan praproses data, maka data yang digunakan sebanyak 7.895 .330 data yang diambil dari pasangan in-out dan dengan maksimal jarak transaksi selama 240 menit.

\section{3) Praproses Data}

Seperti yang telah dijelaskan pada tahapan solusi, praproses data dilakukan untuk mempersiapkan data sumber untuk dapat diproses untuk membangun model. Berdasarkan hasil analisa metode, praposes yang dilakukan adalah pengelompokan data, pairing O-D dari data transaksi, menentukan training set dan testing set, serta pelabelan outlier.

- Pairing O-D dari data transaksi

Pairing dari data transaksi penumpang tap-in dan tap-out. Data transaksi yang terlihat pada Tabel 2 tidak memperlihatkan keterhubungan antara asal dan tujuan dari setiap penumpang. Untuk itu dilakukan pairing antara tap-in dan tap-out. Hal ini dilakukan dengan tujuan mengetahui pasanfan (asal dan tujuan) dari setiap transaksi.

Pairing data dilakukan berdasarkan nomor id kartu yang sama dan jarak waktu antara transaksi. Data terlebih dahulu diurutkan berdasarkan id kartu dan timestamp transaksi. Untuk setiap tap-in dilakukan pencarian transaksi tap-out yang memiliki id kartu yang sama dan juga jarak waktu terdekat.Tabel 3 memuat contoh data hasil pairing O-D.

- Pembagian waktu menjadi beberapa grup 
Pengelompokan berdasarkan zona waktu dilakukan untuk memperoleh korelasi temporal transaksi pengguna transportasi umum secara efektif. Pembangunan zona waktu dilakukan dengan metode data-driven yaitu melihat kecenderungan kepadatan penumpang dan mendefinisikan zona waktu. Metode ini dilakukan agar pembagian zona waktu dapat merepresentasikan kebiasaan pengguna transportasi BRT.

Pengelompokan berdasarkan zona waktu dilakukan untuk memperoleh korelasi temporal transaksi pengguna transportasi umum secara efektif, pada penelitian ini 24 jam dalam sehari dibagi menjadi 12 periode waktu dengan jarak masing-masing 2 jam.

- $00.00-02.00$

- $02.00-04.00$

- $04.00-06.00$

- $06.00-08.00$

- $08.00-10.00$

- $10.00-12.00$

- $12.00-14.00$

- $14.00-16.00$

- $16.00-18.00$

- $18.00-20.00$

- $20.00-22.00$

- $22.00-24.00$

- Mengkategorikan atribut hari

Kategori hari dibagi menjadi dua, yaitu hari libur dan hari kerja. Pengelompokan dilakukan dengan melakukan pendefinisian manual terhadap tanggal libur. Pengelompokan ini dilakukan karena kecenderungan tujuan penumpang pada hari kerja dan hari libur berbeda. Pada hari kerja, kecenderungan tujuan penumpang adalah halte dikawasan perkantoran.

- Pemilihan fitur

Pemilihan fitur bertujuan untuk memilih fitur yang berpengaruh dan mengesampingkan fitur yang tidak berpengaruh dalam suatu kegiatan pemodelan atau penganalisaan data. Ada banyak alternatif yang bisa digunakan dan harus dilakukan secara iterative untuk menemukan fitur yang cocok.

Dalam penelitian ini dipilih beberapa fitur yang berpengaruh untuk melakukan prediksi halte tujuan perjalanan. Fitur-fitur tersebut tercantum pada Tabel 2.

Tabel 2. Fitur-fitur yang digunakan untuk membangun model prediksi tujuan

\begin{tabular}{|c|c|c|}
\hline Fitur & Deskripsi & Information Gain \\
\hline id kartu & Merupakan identitas unik penumpang & 0.422897 \\
\hline in halte & Halte asal penumpang & 0.147459 \\
\hline in_subkoridor & $\begin{array}{l}\text { Pembagian zona koridor asal perjalanan } \\
\text { penumpang }\end{array}$ & 0.134915 \\
\hline in koridor & Jalur/koridor BRT asal perjalanan penumpang & 0.143483 \\
\hline time zone & Pembagian waktu menjadi 12 zona waktu & 0.140807 \\
\hline day category & Hari kerja/hari libur & 0.01044 \\
\hline
\end{tabular}


Tabel 3. Contoh Data O-D dari hasil pairing

\begin{tabular}{|c|c|c|c|c|c|c|c|c|c|c|}
\hline No & Card_ID & Kartu & $\begin{array}{l}\text { In_Dat } \\
\text { etime }\end{array}$ & In_Halte & $\begin{array}{l}\text { In_S } \\
\text { ubko } \\
\text { ridor }\end{array}$ & $\begin{array}{l}\text { In_Korid } \\
\text { or }\end{array}$ & $\begin{array}{l}\text { Out_Dat } \\
\text { etime }\end{array}$ & $\begin{array}{l}\text { Out_H } \\
\text { alte }\end{array}$ & $\begin{array}{l}\text { Out_Sub } \\
\text { koridor }\end{array}$ & Out_Koridor \\
\hline 1 & $\begin{array}{l}14506068 \\
4827\end{array}$ & $\mathrm{BCA}$ & $\begin{array}{l}1 / 1 / 201 \\
80: 01\end{array}$ & Makro & $\begin{array}{l}\text { K-07 } \\
\text { Sout } \\
\text { h }\end{array}$ & $\begin{array}{l}{[7]} \\
\text { Kampung } \\
\text { Rambutan } \\
- \\
\text { Kampung } \\
\text { Melayu } \\
\end{array}$ & $\begin{array}{l}1 / 1 / 2018 \\
0: 36\end{array}$ & $\begin{array}{l}\text { Bidara } \\
\text { Cina }\end{array}$ & $\begin{array}{l}\text { K-07 } \\
\text { North }\end{array}$ & $\begin{array}{l}\text { [7] Kampung } \\
\text { Rambutan } \\
\text { Kampung Melayu }\end{array}$ \\
\hline 2 & $\begin{array}{l}60329393 \\
8205\end{array}$ & MANDIRI & $\begin{array}{l}1 / 1 / 201 \\
80: 01\end{array}$ & $\mathrm{BNN}$ & $\begin{array}{l}\text { K-07 } \\
\text { Midd } \\
\text { le }\end{array}$ & $\begin{array}{l}{[7]} \\
\text { Kampung } \\
\text { Rambutan } \\
- \\
\text { Kampung }\end{array}$ & $\begin{array}{l}1 / 1 / 2018 \\
0: 54\end{array}$ & Pesakih & $\begin{array}{l}\text { K-03 } \\
\text { Outer }\end{array}$ & $\begin{array}{l}\text { [3] Kalideres - } \\
\text { Harmoni - Pasar } \\
\text { Baru }\end{array}$ \\
\hline 3 & $\begin{array}{l}14500355 \\
4812\end{array}$ & $\mathrm{BCA}$ & $\begin{array}{l}1 / 1 / 201 \\
80: 01\end{array}$ & $\begin{array}{l}\text { Central } \\
\text { Park arah } \\
\text { Pluit }\end{array}$ & $\begin{array}{l}\text { K-09 } \\
\text { Inner } \\
\text { East }\end{array}$ & $\begin{array}{l}\text { Melayu } \\
\text { [8] Lebak } \\
\text { Bulus - } \\
\text { Harmoni }\end{array}$ & $\begin{array}{l}1 / 1 / 2018 \\
0: 18\end{array}$ & $\begin{array}{l}\text { Penjari } \\
\text { ngan }\end{array}$ & $\begin{array}{l}\text { K-09 } \\
\text { Outer } \\
\text { West }\end{array}$ & $\begin{array}{l}\text { [9] Pinang Ranti - } \\
\text { Pluit }\end{array}$ \\
\hline 4 & $\begin{array}{l}14500086 \\
9736\end{array}$ & $\mathrm{BCA}$ & $\begin{array}{l}1 / 1 / 201 \\
80: 01\end{array}$ & $\begin{array}{l}\text { Cempaka } \\
\text { Timur }\end{array}$ & $\begin{array}{l}\text { K-10 } \\
\text { Midd } \\
\text { le } \\
\text { Nort } \\
\text { h }\end{array}$ & $\begin{array}{l}{[2] \quad \text { Pulo }} \\
\text { Gadung } 1 \\
\text { - Harmoni }\end{array}$ & $\begin{array}{l}1 / 1 / 2018 \\
1: 02\end{array}$ & $\begin{array}{l}\text { Cempa } \\
\text { ka } \\
\text { Timur }\end{array}$ & $\begin{array}{l}\text { K-10 } \\
\text { Middle } \\
\text { North }\end{array}$ & $\begin{array}{l}\text { [2] Pulo Gadung } 1 \\
\text { - Harmoni }\end{array}$ \\
\hline 5 & $\begin{array}{l}14500092 \\
6618\end{array}$ & $\mathrm{BCA}$ & $\begin{array}{l}1 / 1 / 201 \\
80: 01\end{array}$ & $\begin{array}{l}\text { Cempaka } \\
\text { Timur }\end{array}$ & $\begin{array}{l}\text { K-10 } \\
\text { Midd } \\
\text { le } \\
\text { Nort } \\
\text { h }\end{array}$ & $\begin{array}{l}{[2] \quad \text { Pulo }} \\
\text { Gadung } 1 \\
\text { - Harmoni }\end{array}$ & $\begin{array}{l}1 / 1 / 2018 \\
1: 02\end{array}$ & $\begin{array}{l}\text { Cempa } \\
\text { ka } \\
\text { Timur }\end{array}$ & $\begin{array}{l}\text { K-10 } \\
\text { Middle } \\
\text { North }\end{array}$ & $\begin{array}{l}\text { [2] Pulo Gadung } 1 \\
\text { - Harmoni }\end{array}$ \\
\hline
\end{tabular}

\section{HASIL DAN DISKUSI}

\section{A. Analisis Data}

Data yang digunakan adalah data transaksi tap-in \& tap-out smart card penumpang BRT Transjakarta. Sistem perekamanan menggunakan sistem AFC yang telah dijelaskan pada Bab sebelumnya. Informasi didapatkan setiap kali penumpang melakukan tap/transaksi. Informasi yang didapatkan yaitu timestamp, id kartu, bank penerbit kartu, koridor, subkoridor, halte, dan jenis transaksi masuk atau keluar halte. Contoh data dapat dilihat di Tabel 4.

Tabel 4. Contoh Data Smart card

\begin{tabular}{|c|c|c|c|c|c|c|}
\hline Tanggal_Jam & Pan & Kartu & Koridor & Subkoridor & Halte & Flag \\
\hline $1 / 23.20189: 46$ & 145000100070412 & $\mathrm{BCA}$ & $\begin{array}{l}\text { [1] Blok M } \\
\text { - Kota }\end{array}$ & K-01 South & $\begin{array}{l}\text { Masjid } \\
\text { Agung }\end{array}$ & In \\
\hline $1 / 23.201810: 33$ & 145000100070412 & $\mathrm{BCA}$ & $\begin{array}{l}{[2] \quad \text { Pulo }} \\
\text { Gadung } 1 \text { - } \\
\text { Harmoni }\end{array}$ & $\begin{array}{l}\text { K-02 Inner } \\
\text { North }\end{array}$ & Gambir 2 & Out \\
\hline 1/19/2018 13:08 & 145000100058904 & $\mathrm{BCA}$ & $\begin{array}{l}\text { [1] Blok M } \\
- \text { Kota }\end{array}$ & K-01 North & Olimo & In \\
\hline $1 / 19 / 201813: 47$ & 145000100058904 & $\mathrm{BCA}$ & $\begin{array}{l}\text { [1] Blok M } \\
\text { - Kota }\end{array}$ & K-01 North & $\begin{array}{l}\text { Stasiun } \\
\text { Kota }\end{array}$ & Out \\
\hline
\end{tabular}




\section{B. Pembangunan Model yang diusulkan}

Pembangunan ini dapat menggunakan dua algoritma, yaitu KNN dan decision tree. Training model dilakukan dengan tiga target label prediksi, yaitu halte tujuan penumpang, sub-koridor tujuan penumpang dan koridor tujuan penumpang.

\section{1) K-Nearest Neighbor}

Algoritma KNN memiliki nilai $\mathrm{K}$ yang sangat berpengaruh dalam menentukan hasil klasifikasi. Nilai $\mathrm{K}$ pada kasus ini akan menentukan jumlah perjalanan yang mirip berdasarkan kedekatannya. Nilai optimum $\mathrm{K}$ akan didapatkan dengan melakukan percobaan menggunakan 6 nilai $\mathrm{K}$ yang berbeda, yaitu 50, 20, 10, 5, 3, dan 1 . Proses pengkodean target label dapat dilihat pada Tabel 5 di bawah ini.

Tabel 5. Eksperimen Algoritma KNN

\begin{tabular}{|c|c|c|c|}
\hline No. & Target Label Prediksi & Nilai K & Kode \\
\hline 1. & Halte & $\mathrm{K}=50$ & KNN K50:H \\
\hline 2. & Halte & $\mathrm{K}=20$ & KNN K20: H \\
\hline 3. & Halte & $\mathrm{K}=10$ & KNN K10:H \\
\hline 4. & Halte & $\mathrm{K}=5$ & KNN K5: H \\
\hline 5. & Halte & $\mathrm{K}=3$ & KNN K3:H \\
\hline 6. & Halte & $\mathrm{K}=1$ & KNN K1:H \\
\hline 7. & Sub-Koridor & $\mathrm{K}=50$ & KNN K50: S-K \\
\hline 8. & Sub-Koridor & $\mathrm{K}=20$ & KNN K20:S-K \\
\hline 9. & Sub-Koridor & $\mathrm{K}=10$ & KNN K10: S-K \\
\hline 10. & Sub-Koridor & $\mathrm{K}=5$ & KNN K5 : S-K \\
\hline 11. & Sub-Koridor & $\mathrm{K}=3$ & KNN K3 : S-K \\
\hline 12. & Sub-Koridor & $\mathrm{K}=1$ & KNN K1: S-K \\
\hline 13. & Koridor & $\mathrm{K}=50$ & KNN K50: K \\
\hline 14. & Koridor & $K=20$ & KNN K20: K \\
\hline 15. & Koridor & $\mathrm{K}=10$ & KNN K10:K \\
\hline 16. & Koridor & $\mathrm{K}=5$ & KNN K5 : K \\
\hline 17. & Koridor & $\mathrm{K}=3$ & KNN K3: K \\
\hline 18. & Koridor & $\mathrm{K}=1$ & KNN K1: K \\
\hline
\end{tabular}

\section{2) Algoritma Decision tree}

Pada kasus ini, decision tree memperluas sampai semua leaves memiliki nilai pure atau sampai semua leaves mengandung kurang dari min_sample_split yaitu 2. Sehingga tidak akan dilakukan batasan kedalaman tree. Kode eksperimen dengan menggunakan algoritma Decision Tree ditunjukkan pada Tabel 6.

Tabel 6. Kode Eksperimen Algoritma Decision tree

\begin{tabular}{lll}
\hline \multirow{2}{*}{ Label Prediksi } & \multicolumn{2}{c}{ Atribut Waktu } \\
\cline { 2 - 3 } & Jam & Zona Waktu \\
\hline Halte & DT J:H & DT ZW:H \\
\hline Sub-Koridor & DT J:S-K & DT ZW:S-K \\
\hline Koridor & DT J:K & DT ZW:K \\
\hline
\end{tabular}

\section{3) Analisis Hasil Eksperimen}

Dalam melakukan analisis hasil eksperimen dibagi menjadi 3 bagian yaitu analisis hasil eksperimen algoritma $\mathrm{KNN}$, analisis hasil algoritma decision tree, dan analisis perbandingan algoritma KNN dan decision tree.

\section{a) Analisis Hasil Eksperimen Algoritma KNN}

Nilai $\mathrm{K}$ sangat mempengaruhi hasil prediksi tujuan. Nilai $\mathrm{K}=1$ memberikan hasil yang signifikan lebih baik dibanding dengan $K=3, K=10, K=20$, dan $K=50$. Nilai $K$ yang besar menghasilkan nilai recall, precision, dan f-measure yang lebih rendah 
dibandingkan dengan nilai $\mathrm{K}$ yang kecil. Hal ini karena menggunakan nilai $\mathrm{K}$ yang besar memberikan bias dengan mengambil data point perjalanan individu penumpang yang berbeda. Sedangkan nilai K yang kecil memungkinkan untuk mengambil data point dengan perjalanan individu penumpang yang sama pada zona waktu yang sama.

Ketika $\mathrm{K}$ kecil, akan menahan wilayah prediksi yang diberikan dan memaksa classifier tidak melihat distribusi keseluruhan. Nilai kecil untuk $\mathrm{K}$ memberikan kecocokan paling fleksibel, yang akan memiliki biasa rendah tetapi varians tinggi. Disisi lain, $\mathrm{K}$ yang lebih tinggi melihat lebih banyak data point yang dijadikan pertimbangan di setiap prediksi dan karenanya lebih tahan terhadap pencilan. Nilai K yang lebih besar akan memiliki batas keputusan yang lebih halus yang berarti varians yang lebih rendah tetapi bias meningkat. Hasil evaluasi prediksi halte tujuan perjalanan penumpang dengan menggunakan algoritma KNN ditunjukkan pada Gambar 2, Gambar 3, dan Gambar 4.

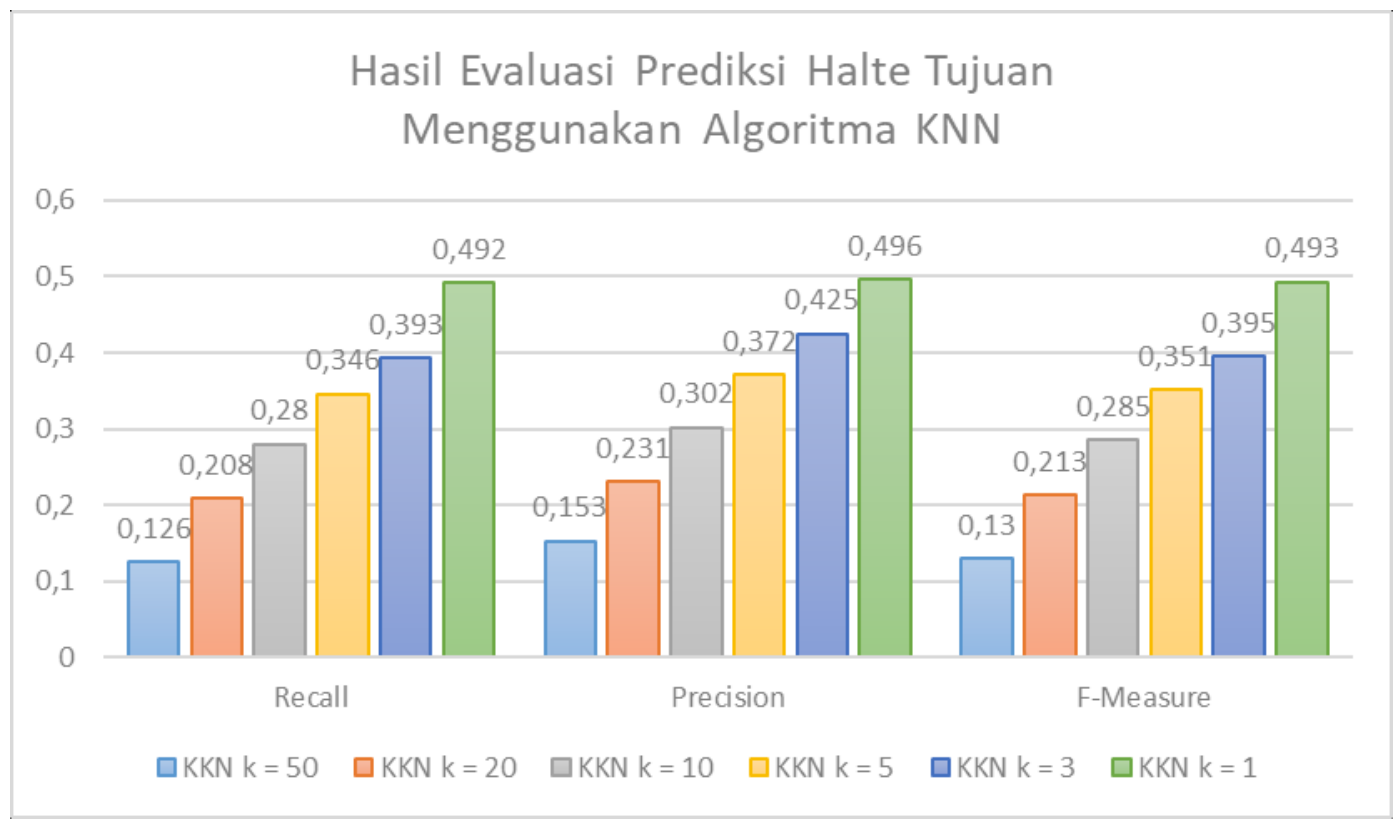

Gambar 2. Hasil Evaluasi Model Prediksi Halte Tujuan Menggunakan Algoritma KNN

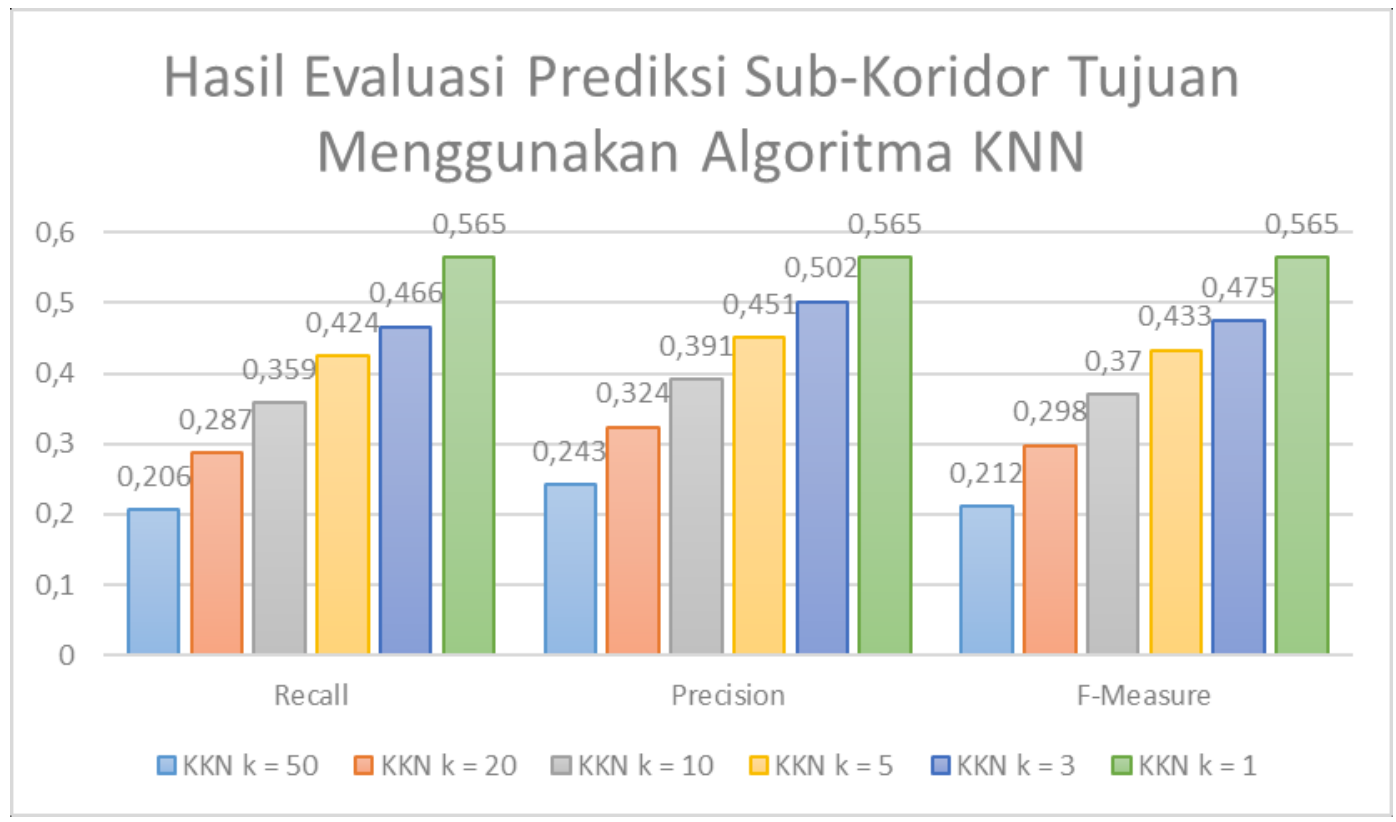


Gambar 3. Hasil Evaluasi Model Prediksi Sub-Koridor Tujuan Menggunakan Algoritma KNN

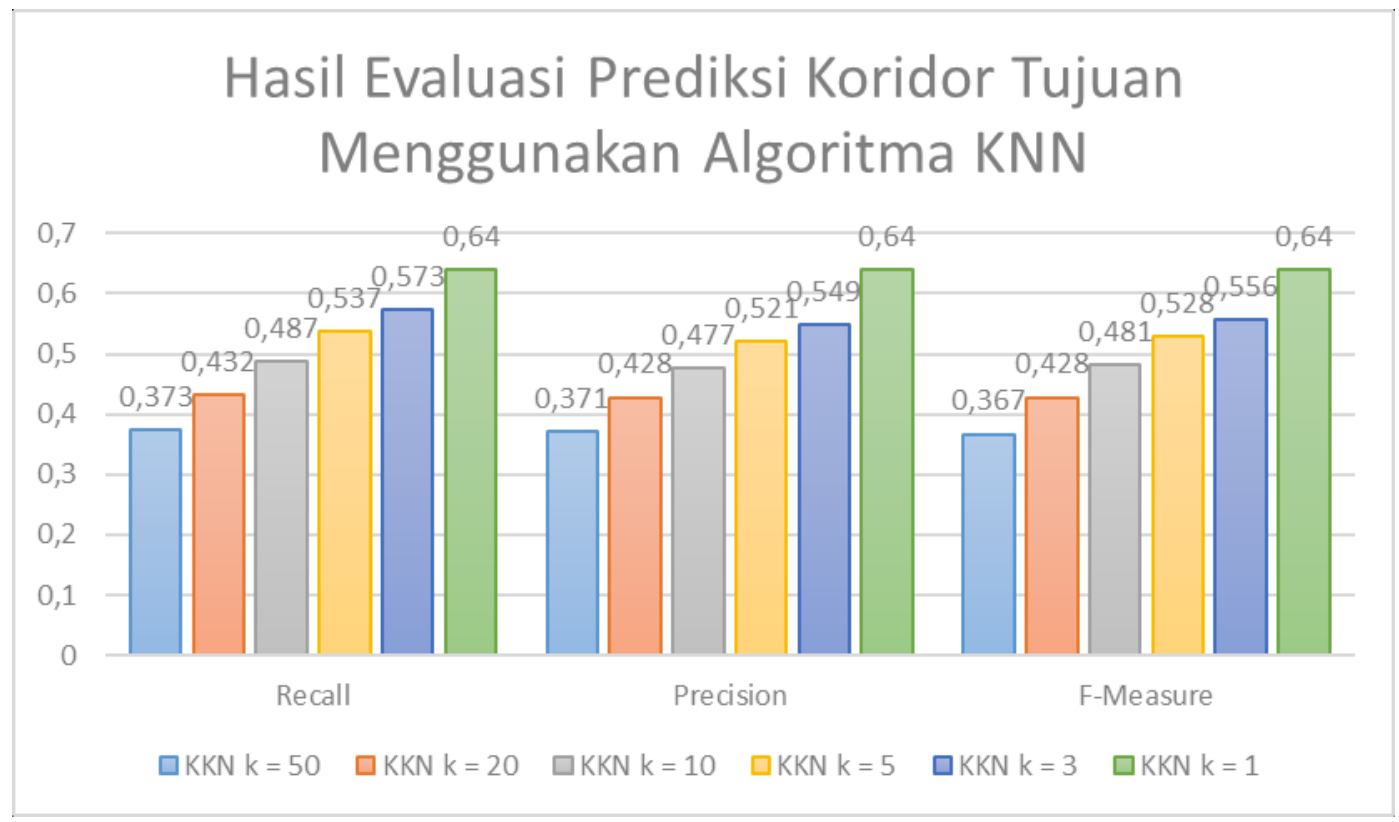

Gambar 4. Hasil Evaluasi Model Prediksi Koridor Tujuan Menggunakan Algoritma KNN

b) Analisis Hasil Eksperiment Algoritma Decision tree

Hasil eksperiment dengan menggunakan algoritma decision tree diketahui dengan menggunakan kategorisasi waktu menjadi zona waktu dapat memberikan nilai akurasi yang lebih baik dibandingkan dengan menggunakan nilai jam. Zona waktu dapat menaikkan nilai recall, precision, dan $f$-measure rata-rata $2,8 \%$. Hasil evaluasi prediksi halte tujuan perjalanan penumpang dengan menggunakan algoritma Decision Tree ditunjukkan pada Gambar 5.

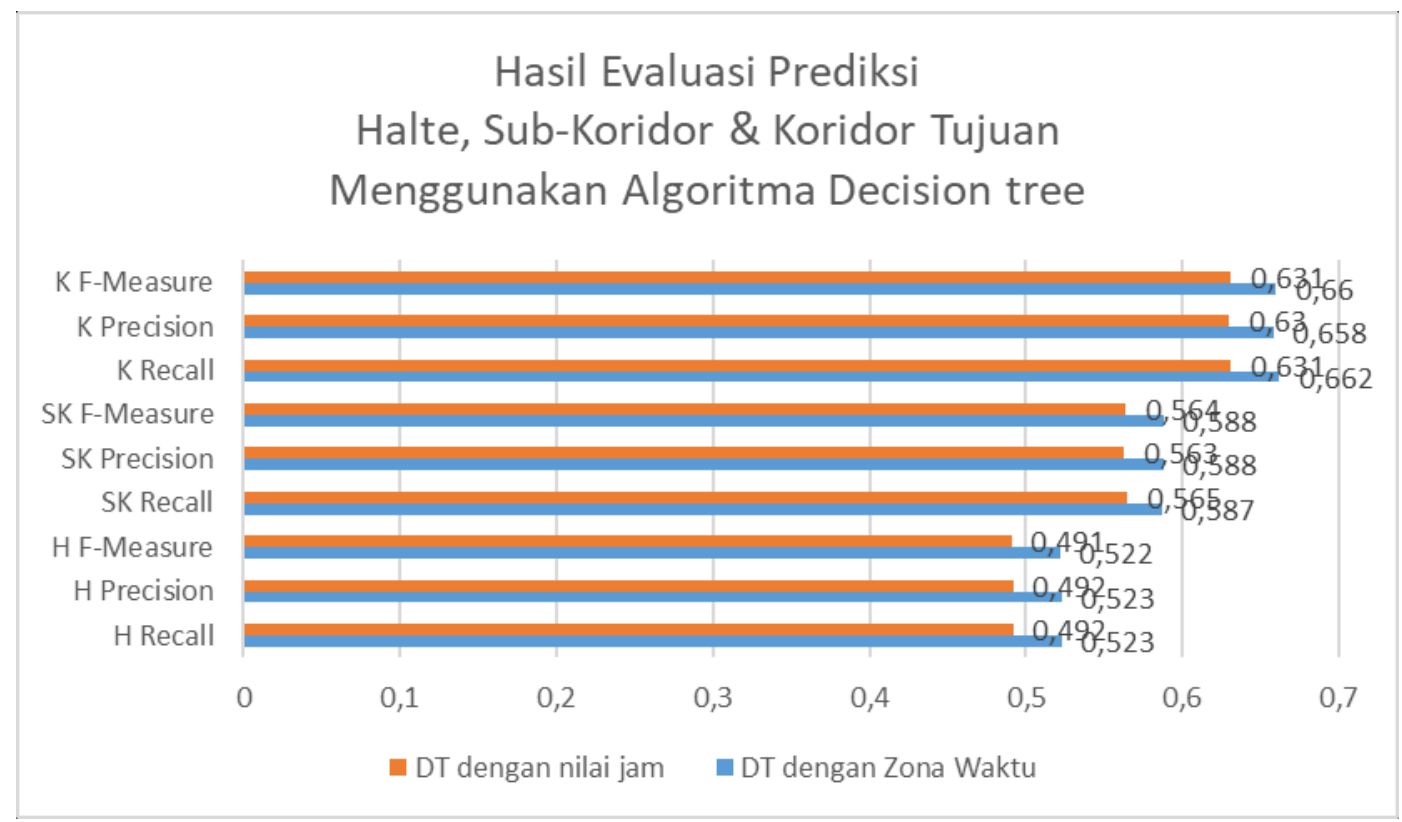

Gambar 5. Hasil Evaluasi Model Prediksi Tujuan Menggunakan Algoritma Decision tree

c) Analisis Perbandingan Hasil KNN Dan Decision tree

Rata-rata nilai recall, precision, dan f-measure decision tree 2,4\% lebih tinggi dari nilai hasil evaluasi dengan KNN. Hal ini dikarenakan decision tree membagi setiap node 
berdasarkan information gain tertinggi yang merupakan informasi perjalanan individu penumpang melalui atribut id_kartu. Sedangkan algoritma KNN merupakan "lazy learner" yang tidak melihat informasi gain dan melakukan prediksi dengan melihat kemiripan data point yang dalam hal ini melihat kemiripan semua atribut secara merata walaupun dengan menggunakan nilai $\mathrm{K}$ terendah. Hasil perbandingan evaluasi model prediksi halte tujuan perjalanan penumpang dengan menggunakan algoritma KNN dan Decision Tree ditunjukkan pada Gambar 6 .

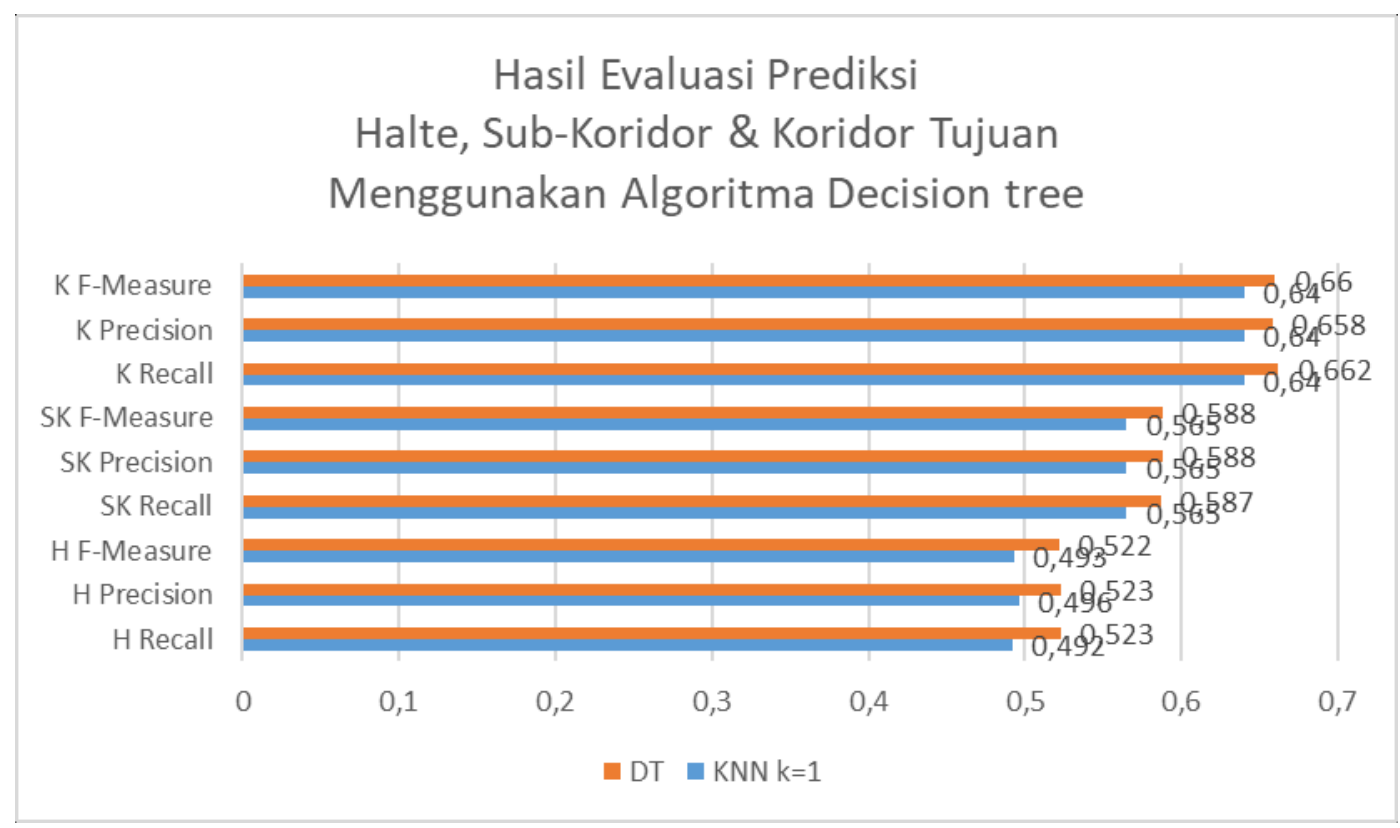

Gambar 6. Perbandingan Hasil Evaluasi Model Prediksi Tujuan Menggunakan Algoritma KNN dan Decision tree

\section{4) Evaluasi model}

Pengujian model terhadap model prediksi dilakukan dengan menggunakan congfusion matrix untuk menghitung recall, precision, dan f-measure.

a) $K N N$

Hasil evaluasi model yang didapatkan dengan menggunakan algoritma KNN dapat dilihat pada Tabel 7.

Tabel 7. Hasil Evaluasi KNN

\begin{tabular}{|c|c|c|c|c|}
\hline No. & Kode Skenario & Recall & Precision & F-measure \\
\hline 1. & KNN K50: H & 0.126 & 0.153 & 0.129 \\
\hline 2. & KNN K20: H & 0.208 & 0.231 & 0.213 \\
\hline 3. & KNN K10: H & 0.280 & 0.302 & 0.285 \\
\hline 4. & KNN K5 : H & 0.346 & 0.372 & 0.351 \\
\hline 5. & $\mathrm{KNN} \mathrm{K3}: \mathrm{H}$ & 0.393 & 0.425 & 0.395 \\
\hline 6. & KNN K1: H & 0.492 & 0.496 & 0.493 \\
\hline 7. & KNN K50: S-K & 0.206 & 0.243 & 0.211 \\
\hline 8. & KNN K20: S-K & 0.287 & 0.324 & 0.298 \\
\hline 9. & KNN K $10:$ S-K & 0.359 & 0.391 & 0.370 \\
\hline 10. & KNN K5 : S-K & 0.424 & 0.451 & 0.433 \\
\hline 11. & KNN K3 : S-K & 0.466 & 0.502 & 0.475 \\
\hline 12. & KNN K1:S-K & 0.565 & 0.565 & 0.565 \\
\hline 13. & KNN K50: K & 0.373 & 0.370 & 0.366 \\
\hline 14. & KNN K20: K & 0.431 & 0.427 & 0.427 \\
\hline 15. & KNN K10: K & 0.487 & 0.477 & 0.481 \\
\hline 16. & KNN K5: K & 0.537 & 0.537 & 0.537 \\
\hline
\end{tabular}




\section{b) Decision tree}

Hasil evaluasi yang didapatkan pada tiap eksperimen, sesuai dengan skenario yang telah didefinisikan pada Tabel 6 dapat dilihat pada Tabel 8 berikut ini.

Tabel 8. Evaluasi Kinerja dengan decision tree

\begin{tabular}{lllll}
\hline No. & Kode Skenario & Recall & Precision & F-measure \\
\hline 1. & DT J $H$ & 0.492 & 0.492 & 0.492 \\
\hline 2. & DT ZW $: H$ & $\mathbf{0 . 5 2 3}$ & $\mathbf{0 . 5 2 3}$ & $\mathbf{0 . 5 2 2}$ \\
\hline 3. & DT J:S-K & 0.565 & 0.563 & 0.564 \\
\hline 4. & DT ZW $:$ S-K & $\mathbf{0 . 5 8 7}$ & $\mathbf{0 . 5 8 8}$ & $\mathbf{0 . 5 8 8}$ \\
\hline 5. & DT J K & 0.631 & 0.630 & 0.631 \\
\hline 6. & DT ZW $: K$ & $\mathbf{0 . 6 6 2}$ & $\mathbf{0 . 6 5 8}$ & $\mathbf{0 . 6 6 0}$ \\
\hline
\end{tabular}

\section{5) Informasi Strategis dari Analisis Menggunakan Decision tree}

Hasil analisis menggunakan decision tree dapat dilihat bahwa terdapat beberapa pasangan koridor dan sub-koridor yang menjadi asal-tujuan yang paling ramai pada jamjam tertentu. Sehingga dapat dilakukan beberapa analisis penyebab ramainya koridor tersebut. Kemudian dari hasil analisis tersebut, dapat dilakukan beberapa keputusan strategis yang berkaitan dengan infrastruktur maupun pelayanan.

Dari hasil evaluasi dengan decision tree, Tabelmenunjukkan bahwa evaluasi kinerja model pembelajaran sudah cukup baik, sehingga dapat dijadikan landasan untuk pengambilan keputusan.. menunjukkan beberapa pasangan Koridor yang memiliki banyak transaksi tap in-out pada zona-zona waktu tertentu. Dari hasil analisis berikut ini, dapat dijadikan sebagai rekomendasi atau pendukung penyusunan analisis lanjut untuk merumuskan strategi. Misalnya dapat dilakukan dengan survei langsung, untuk mengobservasi keadaan langsung di lapangan. Sehingga dapat dilihat gap antara hasil analisis dengan hasil survei

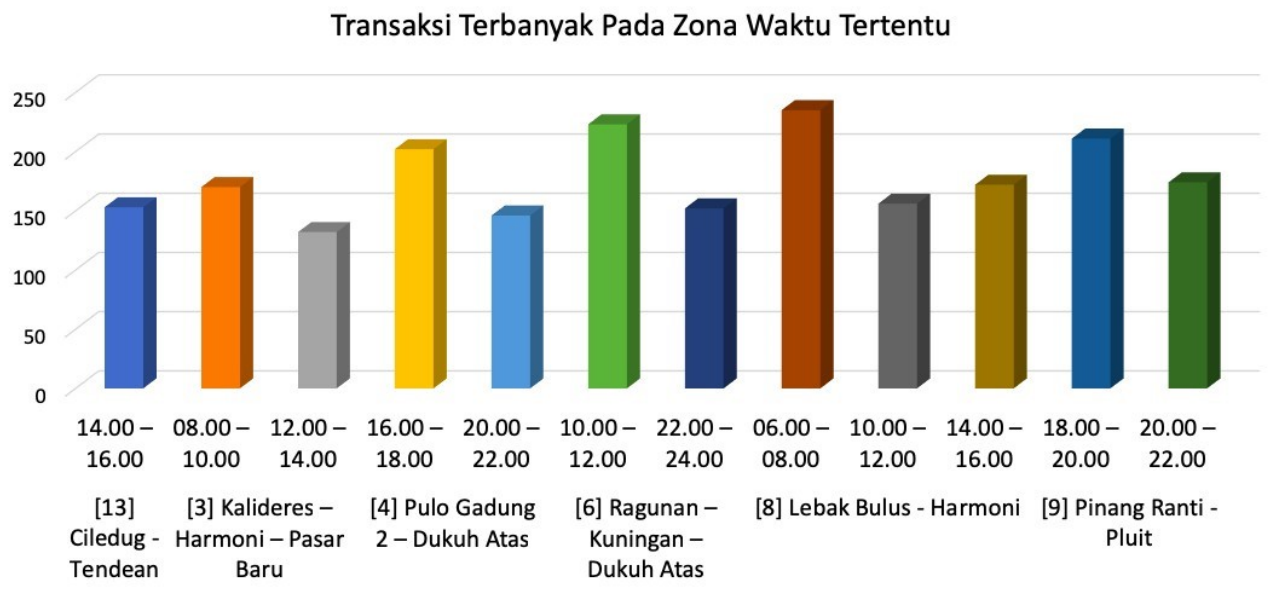

Gambar 7. Sebaran Total Transaksi Terbanyak

Pada Gambar 7 dapat dilihat jam-jam sibuk transaksi tap in-out terbanyak. Pasangan koridor Lebak Bulus - Harmoni pada zona waktu 06.00 - 08.00 merupakan koridor dengan jumlah transaksi tap in-out paling banyak. 


\section{KESIMPULAN}

- Berdasarkan nilai information gain, mengkonversi waktu menjadi kategorikal efektif untuk meningkatkan kinerja model prediksi. Selain itu informasi perjalanan individu penumpang melalui id kartu merupakan atribut yang paling berkorelasi untuk melakukan prediksi tujuan.

- Dibandingkan dengan $\mathrm{KNN}$, kinerja predictive model dengan decision tree memberikan hasil kinerja yang lebih baik dilihat dari nilai precision, recall, dan f-measure. Hal ini dikarenakan decision tree membagi node berdasarkan information gain tertinggi yaitu informasi perjalanan individu penumpang yang paling berkorelasi dengan prediksi tujuan penumpang.

\section{REFERENCES}

[1] T. Wen, C. Cai, L. Gardner, S. T. Waller, V. Dixit, and F. Chen, "Estimation of sparse OD matrix accounting for demand volatility," IET Intell. Transp. Syst., 2018.

[2] C. Sun, L. Cheng, X. Luan, Q. Tu, and J. Ma, "Subnetwork origin-destination matrix estimation considering network topology," Dongnan Daxue Xuebao (Ziran Kexue Ban)/Journal Southeast Univ. (Natural Sci. Ed., 2017.

[3] M. Bagchi and P. R. White, "What role for smart-card data from bus systems?," Proc.Inst. Civ. Eng. - Munic. Eng., 2009.

[4] W. Wang, J. Attanucci, and N. Wilson, "Bus Passenger Origin-Destination Estimation and Related Analyses Using Automated Data Collection Systems," J. Public Transp., 2015.

[5] S. Tao, J. Corcoran, I. Mateo-Babiano, and D. Rohde, "Exploring Bus Rapid Transit passenger travel behaviour using big data," Appl. Geogr., 2014.

[6] T. Li, D. Sun, P. Jing, and K. Yang, "Smart card data mining of public transport destination: A literature review," Information (Switzerland). 2018.

[7] O. J. Ibarra-Rojas, F. Delgado, R. Giesen, and J. C. Muñoz, "Planning, operation, and control of bus transport systems: A literature review," Transportation Research Part B: Methodological. 2015.

[8] Widyawan, B. Prakasa, D. W. Putra, S. S. Kusumawardani, B. T. Y. Widhiyanto, and F. Habibie, "Big data analytic for estimation of origin-destination matrix in Bus Rapid Transit system," in Proceeding - 2017 3rd International Conference on Science and Technology-Computer, ICST 2017, 2017.

[9] J. J. Barry, R. Newhouser, A. Rahbee, and S. Sayeda, "Origin and Destination Estimation in New York City with Automated Fare System Data," Transp. Res. Rec. J. Transp. Res. Board, 2007.

[10] J. Zhao, A. Rahbee, and N. H. M. Wilson, "Estimating a rail passenger trip origindestination matrix using automatic data collection systems," Comput. Civ. Infrastruct. Eng., 2007.

[11] C. Manasseh and R. Sengupta, "Predicting driver destination using machine learning techniques," in IEEE Conference on Intelligent Transportation Systems, Proceedings, ITSC, 2013.

[12] L. H. Tran, M. Catasta, L. K. McDowell, and K. Aberer, "Next Place Prediction using Mobile Data," Proc. Mob. Data Chall. Work. (MDC 2012), 2012.

[13] A. Lo Duca, C. Bacciu, and A. Marchetti, "A K-nearest neighbor classifier for ship route prediction," in OCEANS 2017 - Aberdeen, 2017.

[14] V. Roşca, E. Onica, P. Diac, and C. Amariei, "Predicting Destinations by Nearest Neighbor Search on Training Vessel Routes," 2018.

[15] U. Al-Faruqi, "Survey Paper : Future Service in Industry 5 . 0," vol. 02, no. 01, pp. 67$79,2019$. 